\title{
Field level damage of deepwater rice by the 2011 Southeast Asian Flood in a flood plain of Tonle Sap Lake, Northwest Cambodia
}

\author{
Akihiko Kamoshita • Makara Ouk
}

Received: 3 May 2014/Revised: 10 September 2014/ Accepted: 28 September 2014/Published online: 10 October 2014

(C) The Author(s) 2014. This article is published with open access at Springerlink.com

\begin{abstract}
The 2011 flood damaged about $11 \%$ of planting area in Cambodia, but the damaged proportion reached $30 \%$ in Sangke district, Battambang province, located in the flood plains of Tonle Sap Lake. The aim of this study was to characterize completely damaged deepwater rice production due to the flood along the transect from the town-side shallower fields to the lake-side deeper fields. The flooding water from Tonle Sap Lake rose with $7 \mathrm{~cm} /$ day in September and October in the deeper fields where floating rice was grown and $8-10 \mathrm{~cm} /$ day in October in the shallower fields where lowland rice was grown. The maximum water was recorded on 16 October with 3.2 and $2.0 \mathrm{~m}$ at the deepest and shallowest edge fields. The area was characterized as flatness with only $1.2 \mathrm{~m}$ elevation differences in $4.3 \mathrm{~km}$ distance along the transect. The flooding water took $13.7 \mathrm{~h}$ for approaching $100 \mathrm{~m}$ distance. Complete recession of flood water was end of November at the shallow edge and at late December in the deep edge in 2011. The flooding duration deeper than $50 \mathrm{~cm}$ was 2.5 month and nearly 3 months in the middle zone and deeper floating rice area, respectively. The complete submergence started first in some fields in the middle zone on 12 September, followed by the shallower lowland rice area, and finally in the deep floating rice area by 1 October.
\end{abstract}

Electronic supplementary material The online version of this article (doi:10.1007/s10333-014-0463-x) contains supplementary material, which is available to authorized users.

A. Kamoshita $(\bowtie)$

Asian Natural Environmental Science Center, University of

Tokyo, Midoricho 1-1-1, Nishitokyo 188-0002, Japan

e-mail: akamoshita@anesc.u-tokyo.ac.jp

M. Ouk

Cambodian Agricultural Research and Development Institute,

Phnom Penh, Cambodia
Countermeasures to improve rice production in deepwater rice area in the floodplain of Tonle Sap Lake were proposed.

Keywords Floating rice $\cdot$ Flood damage $\cdot$ Flood-prone rice $\cdot$ Rice ecosystem - Tonle Sap Lake

\section{Introduction}

Deepwater rice was one type of flood-prone rice ecosystem where submergence in depth usually exceeds $100 \mathrm{~cm}$ and continues for durations ranging from more than 10 days to 5 months (Maclean et al. 2002). Rice plants need elongation ability to reach the surface, such as the one found in floating rice up to $5 \mathrm{~m}$ length. Submergence in depth exceeding $100 \mathrm{~cm}$ but less than 10 days was categorized in rainfed lowland ecosystem. Deepwater rice was cultivated in the floodplains and deltas of rivers such as the Ganges and Brahmaputra of India and Bangladesh, the Irrawaddy of Myanmar, the Mekong of Vietnam and Cambodia, the Chao Phraya of Thailand, and the Niger of West Africa (Bouman et al. 2007). In Cambodia, deepwater rice was mostly grown in the floodplain of Tonle Sap Lake, which dramatically seasonally changes water depth as the flooding water of Mekong River intrudes into the Tonle Sap Lake via Tonle Sap River. This flooding pattern was hydrologically very unique and having vast influences on natural ecosystem as well as rice ecosystems in/around the floodplains (Mekong River Commission, MRC 2010). Deepwater rice production in the floodplains of Tonle Sap Lake was however not much studied.

The extreme flood incidence in Indochina peninsula in 2011, so-called 2011 Southeast Asian flood, caused serious damages on agriculture as well as urban life in Southeast 
Asia. Thailand suffered inundation of rice fields as much as 1.3 million ha, while Cambodia also had estimated damaged paddy area of 445 thousand ha, about $16 \%$ of annual harvested rice area (http://en.wikipedia.org/wiki/2011_ Southeast_Asian_floods). It was scarcely recognized that deepwater rice in the floodplains of Tonle Sap Lake was severely damaged resulting in complete crop loss in some local communities.

In general, progress in improving yield of deepwater rice has been slow. The difficulty was unpredictably happening big flood incidences, such as the one in 2011 that nullifies cultivation efforts. In some formerly deepwater rice growing area such as in Thailand and Bangladesh, planting pattern has been changed, in which deepwater rice stopped growing during deep flooding season, but instead short stature lowland rice was planted during dry season using the remaining water (Buddhaboon et al. 2011; Catling et al. 1983; Sommut et al. 2004). The applicability and the magnitude of feasibility of this alternative option in the flood plain of Cambodia were not clarified.

Genetic and physiological basis for adaptation to submergence has been clarified recently; the first strategy was to stay stagnant during a short-term submergence until it recedes, as known as SUB1 gene, while the second was to elongate rapidly (Ismail et al. 2013; Nagai et al. 2010; Septiningsih et al. 2009). While the genetic improvement for better adapted and/or better resilient varieties under flood-prone rice ecosystem was potential breakthrough for the deepwater rice farmers, characterization of deepwater rice ecosystem was prerequisite for both breeding and appropriate choice of available varieties (Catling 1992; Nguyen et al. 2013). The analysis into flood damages on rice fields, such as caused by the 2011 Southeast Asian Flood, may hint possible countermeasures to improve productivity in deepwater rice ecosystems.

In this paper, we presented a case study of flood damages of floating rice in the flood plain of Tonle Sap Lake. The aim was to characterize the process of the flooding with quantitative information.

\section{Materials and methods}

Statistical data for the rice planting area and damaged area from 2006 to 2011 at national, provincial, and district levels were collected from Cambodian Agricultural Research and Development Institute, and from Provincial Department of Agriculture, Battambang, Cambodia.

In order to dissect deepwater rice production in the flood plain of Tonle Sap Lake, a study site was chosen in Kompong Preah commune, Sangke district, Battambang province, Cambodia. Battambang province was one of the most rice producing provinces in Cambodia, including
Table 1 Rice planting and damaged areas in 2011 rainy season for 14 districts in Battambang province

\begin{tabular}{llrrr}
\hline Nos. & Districts & $\begin{array}{c}\text { Planting } \\
\text { area (ha) }\end{array}$ & $\begin{array}{c}\text { Damaged } \\
\text { area (ha) }\end{array}$ & $\begin{array}{c}\text { Replanted } \\
\text { area (ha) }\end{array}$ \\
\hline 1 & Banan & 28,824 & 0 & 0 \\
2 & Thmor Koul & 64,503 & 9,456 & 2,217 \\
3 & Battambang & 6,294 & 0 & 0 \\
4 & Borvil & 29,850 & 0 & 0 \\
5 & Ek Phnom & 11,067 & 5,180 & 1,260 \\
6 & Moung Russey & 52,500 & 10,282 & 1,600 \\
7 & Ratanak Mondul & 4,423 & 0 & 0 \\
8 & Sangke & 32,980 & 10,082 & 700 \\
9 & Samlaut & 2,921 & 0 & 0 \\
10 & Sampao Loun & 3,288 & 0 & 0 \\
11 & Phnom Preik & 2,500 & 0 & 0 \\
12 & Kamreang & 4,652 & 0 & 0 \\
13 & Keas Kralar & 20,544 & 0 & 0 \\
14 & Rukhakiri & 21,861 & 0 & 0 \\
Total & & 286,207 & 35,000 & 5,777 \\
\hline
\end{tabular}

Source Battambang Provincial Department of Agriculture

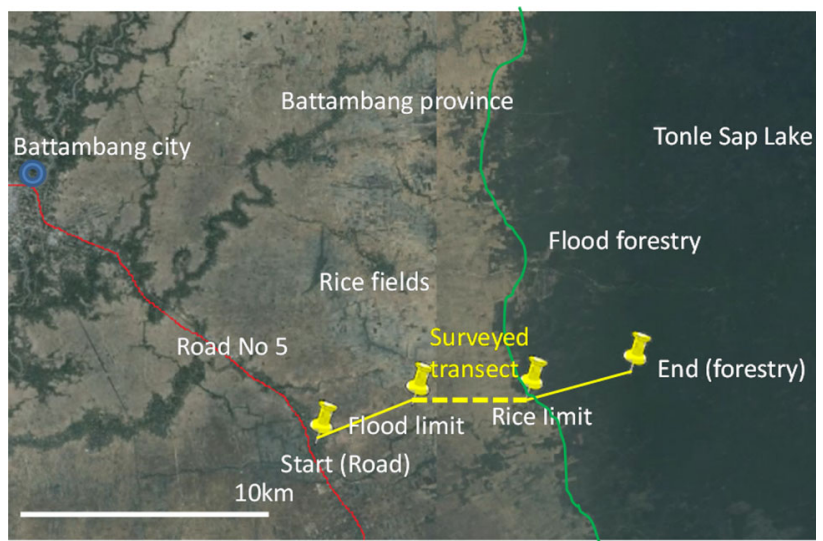

Fig. 1 Map of the transect survey site in Sangke district, Battambang province, Cambodia. The whole $13.3 \mathrm{~km}$ from the road No. 5 to the forestry was preliminary surveyed, from which the transect of $4.3 \mathrm{~km}$ between flood limit and rice limit was selected for this study

"late maturing rice" and "floating rice" according to Cambodian agricultural statistics. Among the 14 districts in Battambang province, Sangke district was the most popular for growing deep water rice in Tonle Sap flood plain, together with the other 3 districts located on the floodplain of Tonle Sap Lake, Thmor Koul, Moung Russey, Ek Phnom districts (Table 1; Fig. 1).

A field survey was made from the entrance start point from the national road No. 5 to the flood forestry toward the Tonle Sap Lake for about $13.3 \mathrm{~km}$ length (Fig. 1). The surveyed transect was set from the field around which was 
the limit of flood water from the lake in normal years (about $4 \mathrm{~km}$ from the road No. 5 , i.e., shallower side) to the boundary between rice growing area and flood forestry area (i.e., deeper side). This transect was $4.3 \mathrm{~km}$. Rainfed lowland rice was predominantly grown in the flood limit area, while floating rice was increasingly grown in the deeper area along the transect (Fig. 1).

Along the transect line where 87 fields in total were located in both side, 31 key fields were selected randomly (average distance from the neighboring 2 key fields was about $140 \mathrm{~m}$ ). In 2009 when flood pattern was recognized as within normal range with minor flood damage by the local villagers, plant height at maturity was measured for each key field. Water depth of the 10 of the key fields was recorded about every 2 weeks during rainy season, and maximum recorded level of water depth was identified on 12 October 2009. In 2011, water depth of all the 31 key fields was recorded twice a month from 3 August 2011 to 16 December 2011. The dates of the reach of the flooding water from the lake, complete submergence of the rice plants, and complete recession of the water from the field were recorded by daily observation for every key field. Rice variety names and its types (lowland rice or floating rice) were recorded by field survey and farmer interviews in 2009, 2010, and 2011.

Amounts of rainfall were recorded by Provincial Department of Water Resources and Meteorology, with $1,356 \mathrm{~mm}$ (89 days) in 2009 and $1,704 \mathrm{~mm}$ (85 days) in 2011. Data of maximum depth of Tonle Sap Lake were measured by the recording system at Chong Kneas Station (Masumoto et al. 2007).

\section{Results and discussion}

\section{Rice damage statistics}

The smallest annual damaged rice area (including all the rice types in whole Cambodia) by flood from 2006 to 2010 was 1,310 ha (2008) and the largest was 41,163 ha (2009; Table 2). Compared with these values, the damage in 2011 was much larger, 267,184 ha and more than $10 \%$ of the whole country's planting area during the rainy season 2011. The same yearly tendency of flood damage was observed in Battambang province where $12 \%$ of planting area in 2011 (i.e., 35,000 ha) was damaged. The severely damaged districts in Battambang province were Moung Russey, Sangke, Thmor Koul, Ek Phnom districts, those located in the floodplains of Tonle Sap Lake (cf. Table 1). The proportion of damaged area in 2011 was as large as $31 \%$ of the planted area in Sangke district.

The Cambodian rice production was grouped as "floating rice," "late maturing rice," "medium maturity rice," "early maturity rice," and "upland rice." In 2010 where flood damage was negligible or little in Battambang province and Sangke district, the proportion of harvest area each of the rice type was $9,33,35,17$, and $0 \%$ for floating rice, late maturing rice, medium maturing rice, early maturing rice, and upland rice, respectively (Table 3 ). The proportions were $32,44,18,6$, and $0 \%$ in Sangke district, with greater proportion of floating rice and late maturing rice.

The extent of flood damages for each rice category in 2009 (mild damage) and 2011 (severe damage) was indicated from the changes in harvest area from 2010 (Table 3). In Battambang province, reduction in floating rice and late maturing rice in 2011 was conspicuous, while in 2009, medium maturing rice reduced to a greatest extent. In Sangke district in 2011, late maturing rice, early maturing rice, and floating rice had smaller harvest area than those in 2010, indicating flood damages in these rice categories (Table 3). It should be remembered that planting area in Battambang province (i.e., Table 2) was increased by ca. 7,000 ha from 2009 to 2010 and by ca. 17,000 ha from 2010 to 2011, while the corresponding increases in Sangke district were 1,000 and 1,200 ha, respectively. As there was no information about planting area of each rice category, the yearly changes in harvest area in each rice category should be taken as indicative data for the flooddamaged area.

In Battambang province, amounts of rice production were dominant in late and medium maturing rice types, which was followed by early maturing rice and floating rice (Table 4). The level of yield was highest for late maturing rice, followed by medium, then early, and then floating rice in 2010. The yield in 2009 was reduced for late, medium, and early maturing rice types compared with the 2010 in Battambang province, while in 2011, yield did not largely reduced but increased. The reduction in production in 2009 was mainly for medium maturing rice and to a minor extent for early maturing rice and floating rice, whereas in 2011, the reduction was more by late maturing rice and floating rice, followed by medium maturing rice.

In Sangke district, the proportion of late maturing rice and floating rice were much greater compared with Battambang province. Yield of floating rice in 2009 reduced compared with 2010. In 2011, yield tended to increase for late and early maturing rice types. Production of floating rice and medium maturing rice in 2009 and of floating rice and late maturing rice in 2011 was substantially reduced.

In the severely flood-damaged districts, rice was replanted as recession rice, a type of dry season rice utilizing receding flood water for rice production, after the damage during the end of 2011 rainy season to early 2012 dry season (December 2011-April 2012). Floodplain in Sangke district was however so flat with few geomorphological 
Table 2 Rice planting and damaged areas in whole Cambodia, Battambang province and Sangke district, and maximum water depth of Tonle Sap Lake from 2006 to 2011

\begin{tabular}{|c|c|c|c|c|c|c|c|c|c|c|}
\hline \multirow[t]{3}{*}{ Years } & \multicolumn{3}{|l|}{ Cambodia } & \multicolumn{3}{|c|}{ Battambang province } & \multicolumn{3}{|c|}{ Sangke district } & \multirow{3}{*}{$\begin{array}{l}\text { Tonle Sap Lake } \\
\text { Maximum water } \\
\text { depth (m) }\end{array}$} \\
\hline & \multirow{2}{*}{$\begin{array}{l}\text { Planting area } \\
\left(10^{3} \mathrm{ha}\right)\end{array}$} & \multicolumn{2}{|c|}{ Damaged area } & \multirow{2}{*}{$\begin{array}{l}\text { Planting } \\
\text { area }\left(10^{3} \text { ha }\right)\end{array}$} & \multicolumn{2}{|c|}{ Damaged area } & \multirow{2}{*}{$\begin{array}{l}\text { Planting } \\
\text { area }\left(10^{3} \text { ha }\right)\end{array}$} & \multicolumn{2}{|c|}{ Damaged area } & \\
\hline & & $\left(10^{3}\right.$ ha $)$ & $(\%)$ & & $\left(10^{3} \mathrm{ha}\right)$ & $(\%)$ & & $\left(10^{3}\right.$ ha $)$ & $(\%)$ & \\
\hline 2006 & 2,212 & 18 & 0.8 & 244 & 0.2 & 0.1 & 30.5 & 0.1 & 0.3 & 8.21 (18 October) \\
\hline 2007 & 2,241 & 31 & 1.4 & 240 & 0.4 & 0.2 & 30.7 & 0.0 & 0.0 & 7.76 (24 October) \\
\hline 2008 & 2,255 & 1 & 0.1 & 245 & 0.5 & 0.2 & 31.3 & 0.0 & 00 & 7.54 (7 October) \\
\hline 2009 & 2,334 & 41 & 1.8 & 262 & 4.0 & 1.5 & 30.8 & 1.1 & 3.6 & 8.14 (12 October) \\
\hline 2010 & 2,391 & 17 & 0.7 & 269 & 0.3 & 0.1 & 31.8 & 0.0 & 00 & 6.63 (27 October) \\
\hline 2011 & 2,497 & 267 & 10.7 & 286 & 35.0 & 12.2 & 33.0 & 10.1 & 30.6 & 9.45 (21 October) \\
\hline
\end{tabular}

a Daily recorded at Chong Kneas Station (provided from Dr. T. Masumoto)

Table 3 Harvest area of each rice category (floating rice, late, medium, early maturing rice, and upland rice) in Sangke district and Battambang province in 2010 (no flood year) compared with the flood damage years 2009 and 2011

\begin{tabular}{|c|c|c|c|c|c|c|c|}
\hline \multirow[t]{2}{*}{ Locations } & \multirow[t]{2}{*}{ Years } & \multicolumn{6}{|c|}{ Harvest area $\left(10^{3}\right.$ ha $)$} \\
\hline & & Floating & Late & Medium & Early & Upland rice & Total \\
\hline \multirow[t]{9}{*}{ Sangke district } & \multicolumn{7}{|c|}{2010 (No flood year) } \\
\hline & & 10.2 & 13.9 & 5.6 & 1.9 & 0 & 31.8 \\
\hline & (\% total) & $(32)$ & (44) & (18) & (6) & $(0)$ & $(100)$ \\
\hline & \multicolumn{7}{|c|}{2009 (Flood year) } \\
\hline & & 8.3 & 14.1 & 4.7 & 2.6 & 0 & 29.7 \\
\hline & $(\%$ 2010) & $(81)$ & $(101)$ & (83) & $(135)$ & - & (93) \\
\hline & \multicolumn{7}{|c|}{2011 (Flood year) } \\
\hline & & 8 & 8.4 & 5.9 & 1.3 & 0 & 23.6 \\
\hline & $(\%$ 2010) & (79) & $(61)$ & (104) & $(66)$ & - & (74) \\
\hline \multirow[t]{9}{*}{ Battambang province } & \multicolumn{7}{|c|}{2010 (No flood year) } \\
\hline & & 24.9 & 88 & 94.5 & 45.8 & 2.7 & 269.2 \\
\hline & (\% total) & (9) & (33) & $(35)$ & (17) & (1) & $(100)$ \\
\hline & \multicolumn{7}{|c|}{2009 (Flood year) } \\
\hline & & 20.3 & 106.2 & 73.6 & 39.7 & 8.8 & 257.7 \\
\hline & (\% 2010) & $(81)$ & $(121)$ & $(78)$ & (87) & $(327)$ & (96) \\
\hline & \multicolumn{7}{|c|}{2011 (Flood year) } \\
\hline & & 15.7 & 73.9 & 92.1 & 73.7 & 1.6 & 257.7 \\
\hline & (\% 2010) & (63) & (84) & (97) & (161) & (58) & (95) \\
\hline
\end{tabular}

elevation differences (cf. Nguyen et al. 2013) that development of large-scale recession rice cultivation was not easy at present in 2011-2012. Only 700 ha of recession rice in Sangke district while planting area for recession rice was much greater in Thmor Koul, Moung Russey, Ek Phnom districts (cf. Table 1), due to the easiness to capture receding flood water at the end of the rainy season in the small geomorphological elevation differences.

Water depth of Tonle Sap Lake has been measured since 2003 at Chong Kneas Station (Masumoto et al. 2007), but no studies have linked it with deepwater rice production. The maximum water depth in Tonle Sap Lake during 2006-2011 was by far the largest in $2011(9.45 \mathrm{~m})$, and the rice-damaged areas were largest in 2011 both in Battambang province and in Sangke district (Table 2). The second and the third deepest years were in 2006 and 2009, in both of which rice damage was recognized in Sangke district with much greater degrees in 2009. In the other 3 years, rice-damaged areas were recognized to a minor degree in Battambang province but not in Sangke district. Although maximum depth of Tonle Sap Lake in October was not the only factor for the flood damage in deepwater rice production in the floodplain of the lake, in case of 2011, volumes of water in the lake were associated with the largest flood damage. 
Table 4 Grain yield and production of each rice category (floating rice, late, medium, early maturing rice, and upland rice) in Sangke district and Battambang province in 2010 (no flood year) compared with the flood damage years 2009 and 2011

\begin{tabular}{|c|c|c|c|c|c|c|c|c|c|c|c|c|}
\hline \multirow[t]{2}{*}{ Location } & \multirow[t]{2}{*}{ Years } & \multicolumn{5}{|c|}{ Yield (t/ha) } & \multicolumn{6}{|c|}{ Production $\left(10^{3} \mathrm{t}\right)$} \\
\hline & & Floating & Late & Medium & Early & $\begin{array}{l}\text { Upland } \\
\text { rice }\end{array}$ & Floating & Late & Medium & Early & $\begin{array}{l}\text { Upland } \\
\text { rice }\end{array}$ & Total \\
\hline \multirow[t]{3}{*}{ Sangke district } & $\begin{array}{l}2010 \text { (No flood } \\
\text { year) }\end{array}$ & 2.2 & 2.7 & 2.4 & 2.2 & - & 23 & 38 & 14 & 4 & 0 & 79 \\
\hline & 2009 (Flood year) & 1.8 & 2.6 & 2.4 & 2.4 & - & 15 & 37 & 11 & 6 & 0 & 69 \\
\hline & 2011 (Flood year) & 2.0 & 3.3 & 2.5 & 3.2 & - & 16 & 28 & 15 & 4 & 0 & 62 \\
\hline \multirow[t]{3}{*}{$\begin{array}{l}\text { Battambang } \\
\text { province }\end{array}$} & $\begin{array}{l}2010 \text { (No flood } \\
\text { year) }\end{array}$ & 2.2 & 3.0 & 2.8 & 2.6 & 2.6 & 55 & 263 & 264 & 118 & 7 & 707 \\
\hline & 2009 (Flood year) & 2.1 & 2.6 & 2.3 & 2.1 & 2.7 & 43 & 277 & 170 & 85 & 23 & 599 \\
\hline & 2011 (Flood year) & 2.1 & 3.2 & 2.7 & 3.1 & 2.8 & 33 & 235 & 249 & 226 & 4 & 748 \\
\hline
\end{tabular}

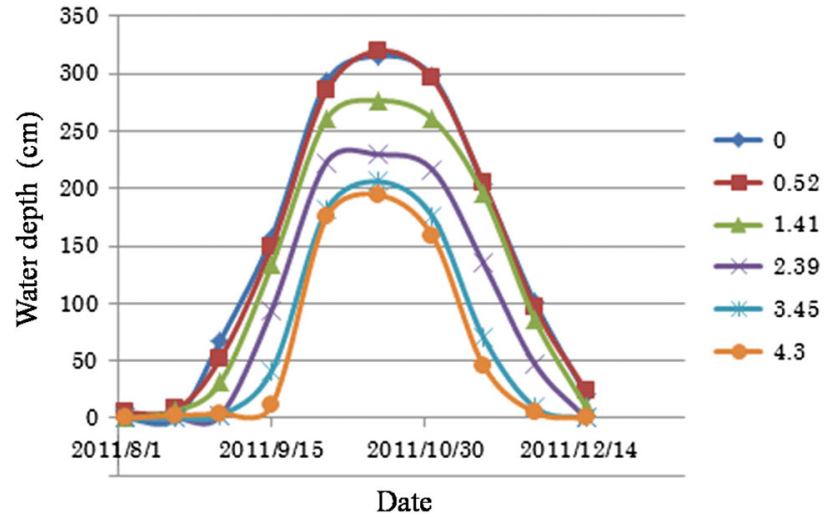

Fig. 2 Seasonal changes in water depth during the flooding period 2011 at the key paddy fields located along the transect, Sangke district, Battambang province, Cambodia. Numbers for each symbol show the distance from the rice limit field [i.e., $0(\mathrm{~km})=$ rice limit filed at most lakeside deepest edge, $4.3(\mathrm{~km})=$ flood limit field at shallowest edge]

Flood characterization along the transect

In August, the paddy fields along the transect of $4.3 \mathrm{~km}$ were mostly saturated, without standing water (Fig. 2). Deep flooding started from the fields at the edge of the transect nearby the lake (i.e., rice limit) from the end of August to middle September at the other shallower edge nearby the national road (i.e., flood limit). The speed of water depth increment (i.e., slope of Fig. 2) during the 31 days from 31 August to 1 October was about $7 \mathrm{~cm} /$ day in the lakeside fields and $8-10 \mathrm{~cm} /$ day in the shallower fields for the 16 days from 15 September to 1 October. The corresponding values were much smaller in 2009, 5 and $2.5 \mathrm{~cm} /$ day, respectively (data not shown). Very high rates of elongation of floating rice have been reported in Bangladesh (e.g., $20-30 \mathrm{~cm} /$ day), which were however instantaneous maximum values. Strong elongation cultivars became completely submerged and dead with the water depth increases of more than $10 \mathrm{~cm} /$ day over 20 days and of $8 \mathrm{~cm} /$ day for 26 days (Catling 1992). Compared with these studies, the $7 \mathrm{~cm} /$ day increment in the lakeside field in our study was a little bit slower but almost comparable, but the duration of depth increment was longer (31 days plus more gentle additional increase for 15 days till 16 October), which has caused complete death of floating rice cultivars.

Maximum water depth (i.e., peak in Fig. 2) was recorded on 16 October 2011, with the rice limit field $3.2 \mathrm{~m}$ and the flood limit field $2.0 \mathrm{~m}$. Elevation differences of the $4.3 \mathrm{~km}$ transect were assumed to $1.2 \mathrm{~m}$ from these values, quantitatively showing the flatness and the very gentle slope in the floodplain of Sangke district. Flat and vast area, with relatively fertile soil type in deepwater rice ecosystem in Cambodia (Nesbitt 1997), was suitable for large-scale lowland rice/floating rice production in rainy season, while storage of irrigation water for dry season rice was limited by this geomorphological nature. The conversion of cropping system from long duration floating rice production during rainy season to short duration rice production during dry season has been done in some part of deepwater rice ecosystems in tropical Asia, such as in Bangladesh and Thailand (Buddhaboon et al. 2011; Catling et al. 1983; Hossain et al. 2004; Puckridge et al. 2000). Dry season rice was also known to be cultivated in the floodplain of Mekong River in Cambodia where receding water was more easily stored and more readily available during dry season. In order to develop this new rice production system in the flood plain of Tonle Sap Lake, not only construction of large water reservoirs was needed, but also assessment of effects on ecosystem services as agrochemical inputs should increase in such a system, while Tonle Sap Lake and its surrounding floodplain ecosystem were unique natural heritage in Cambodia (Kummu et al. 2006). 
Fig. 3 Dates of initiation of flooding (crosses), complete submergence (circles), and complete receded (diamonds) along the transect; the distance $(\mathrm{km})$ from the deepest field [=most lakeside field (rice limit)] was shown in $x$-axis

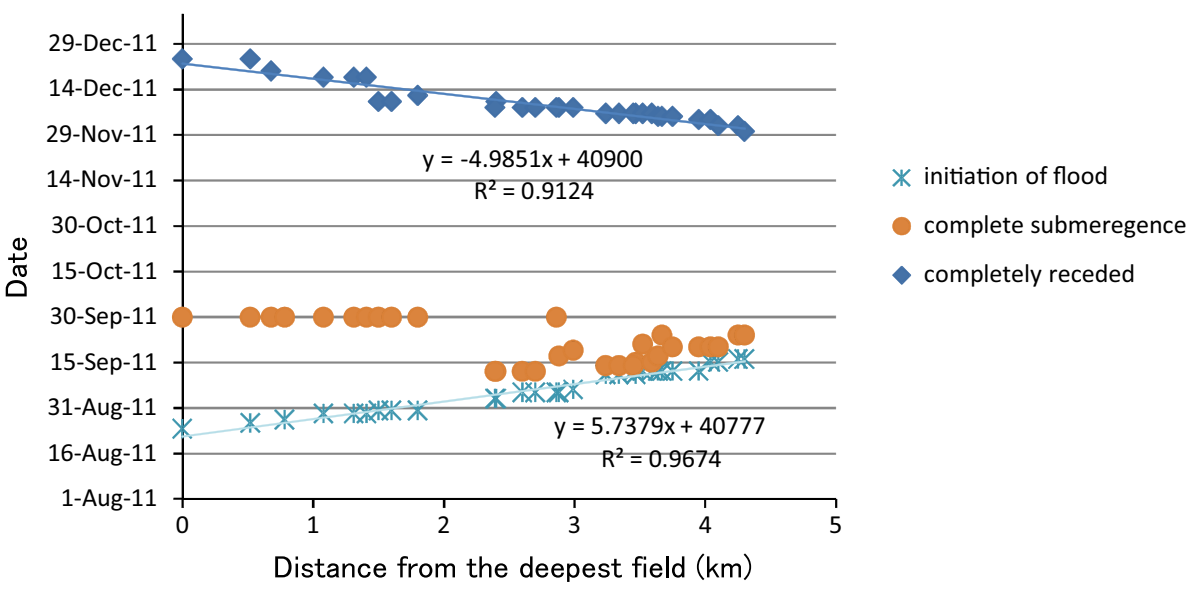

Water level was maintained deep by the early November, which sharply declined during November, with $5.6-6.6 \mathrm{~cm} /$ day from 1 November to 1 December in the lakeside fields while $7.0-7.5 \mathrm{~cm} /$ day from 1 to 15 November in the shallower fields.

The initiation of flooding from the lake progressed from the rice limit field moving $1 \mathrm{~km}$ in about 5.7 days (i.e., $175 \mathrm{~m} /$ day or $7.3 \mathrm{~m} / \mathrm{h}$, Fig. 3). The complete recession of the flooded water started at the flood limit field from the end of November and moved to the rice limit field with the speed of $1 \mathrm{~km}$ in 5 days, a slightly faster $(200 \mathrm{~m} /$ day or $8.3 \mathrm{~m} / \mathrm{h}$ ) than the speed of flood initiation. Complete submergence started from 12 September at the several fields located from 2.4 to $3.6 \mathrm{~km}$ from the rice limit field (called middle zone where farmers could plant either floating rice or lowland rice varieties Nguyen et al. 2013). Then the shallower fields where lowland varieties were grown were completely submerged by 24 September and within a week; the rice limit field of floating rice varieties became also submerged by 1 October.

Figure $4 \mathrm{a}, \mathrm{b}$ showed spatial distribution of water depth at different dates during flooding period 2011 along the transect, in which differences in water depth about 1-1.5 m were observed between the shallower side and lakeside paddy fields. This difference however significantly affected choices of rice variety at different positions along the transect. In the area where maximum water depth was shallower than $50 \mathrm{~cm}$ depth, rainfed lowland rice varieties were suited, while floating rice varieties were suitable in the areas exceeding $1 \mathrm{~m}$ for longer than 10 days (Maclean et al. 2002). Hence, from 0 to $2.4 \mathrm{~km}$ from the rice limit field at the lakeside edge of the transect, only floating rice varieties were chosen according to the survey from 2009 to 2011; the early December flowering Sar Kranhanh, and middle December flowering Veal Veng varieties (Nguyen et al. 2013). From 3.6 to $4.3 \mathrm{~km}$, only lowland rice varieties Raing Chey and Phkar Khnei were chosen. In between 2.4 and $3.6 \mathrm{~km}$ where we defined as middle zone, both
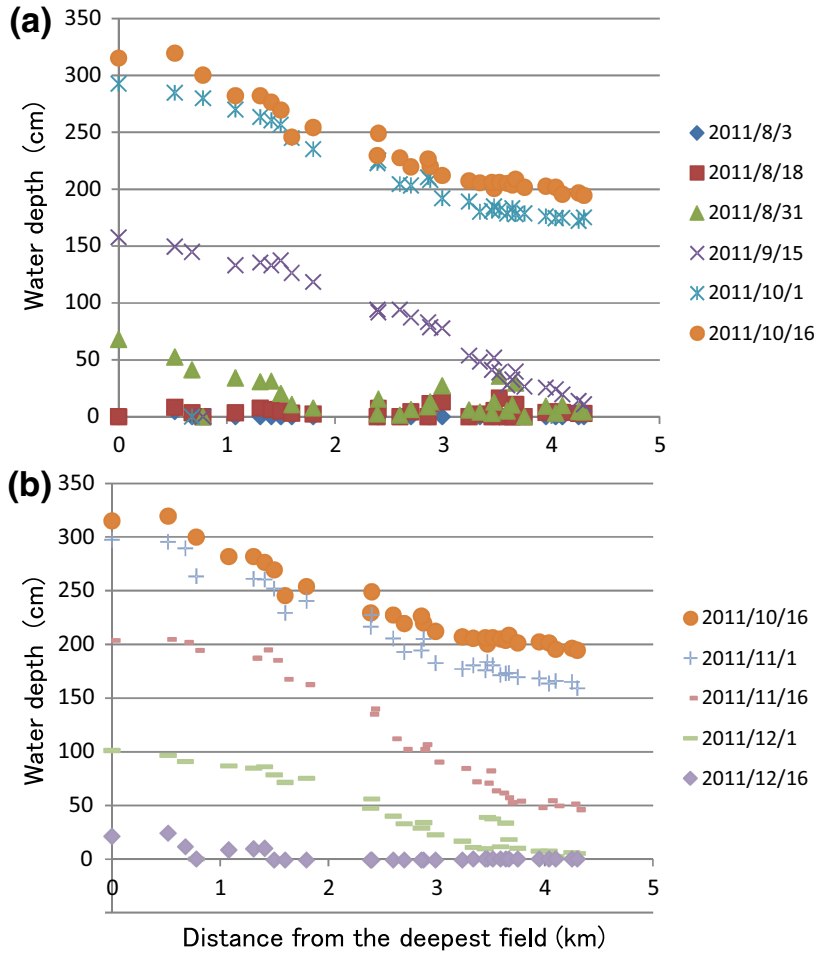

Fig. 4 Spatial distribution of water depth along the transect during the flooding period. a Flooding period from 3 August to 16 October 2011, and b receding period from 16 October to 16 December 2011; the distance $(\mathrm{km})$ from the deepest field [=most lakeside field (rice limit)] was shown in $x$-axis

floating rice (i.e., Veal Veng, Veal Sra) and lowland rice varieties (Raing Chey) were chosen. The farmers' choices of rice varieties along the surveyed transect from 2009 to 2011 are shown in Table 5 that clearly showed this middle zone. As suggested from the large yearly differences in the maximum water depth of Tonle Sap Lake for the recent 6 years (cf. Table 2), it was not easy to forecast the exact degree of flood before farmers plant rainy season rice in April or May in the floodplain with the current available hydrological governance system of Mekong River and 


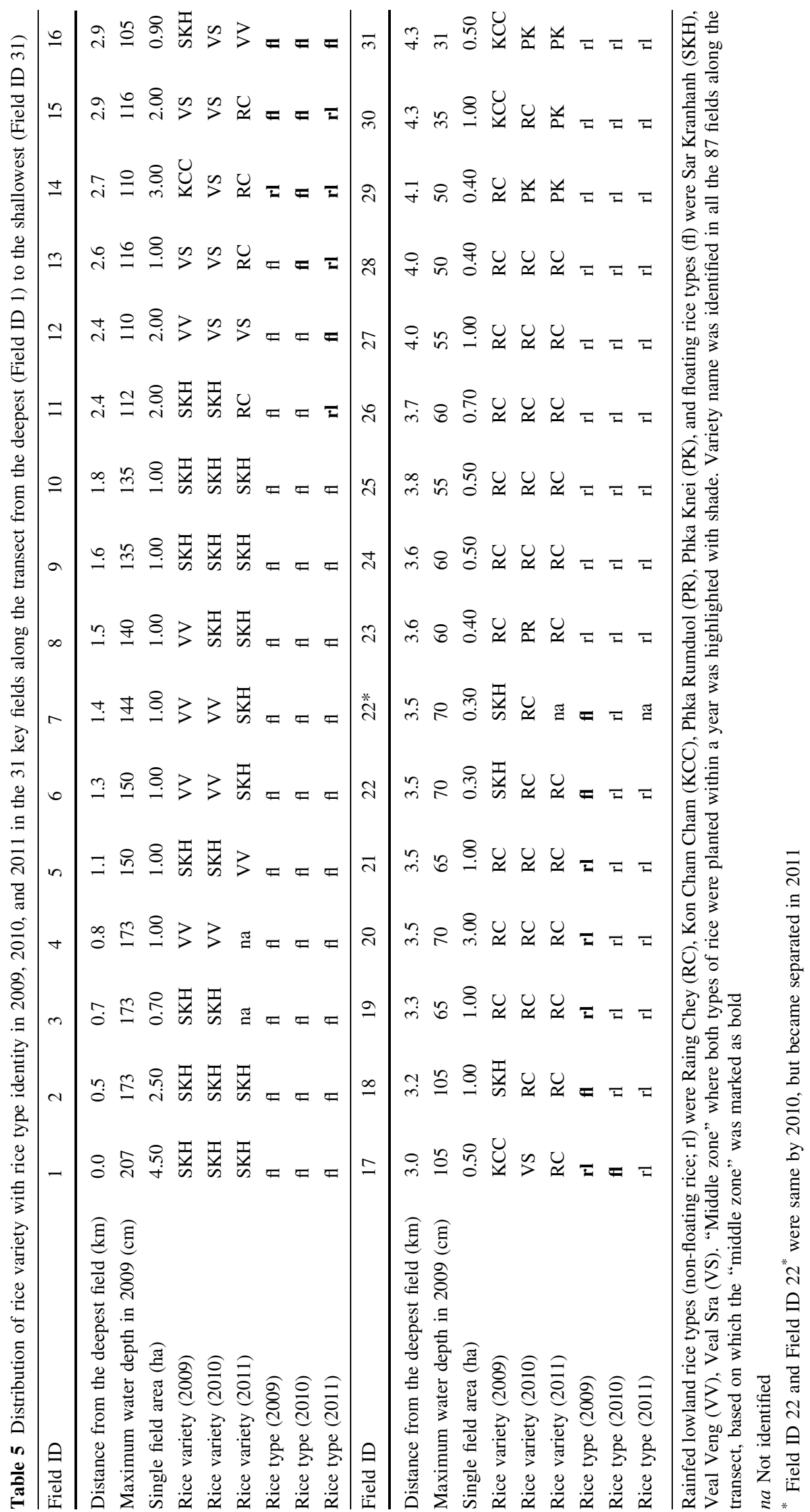




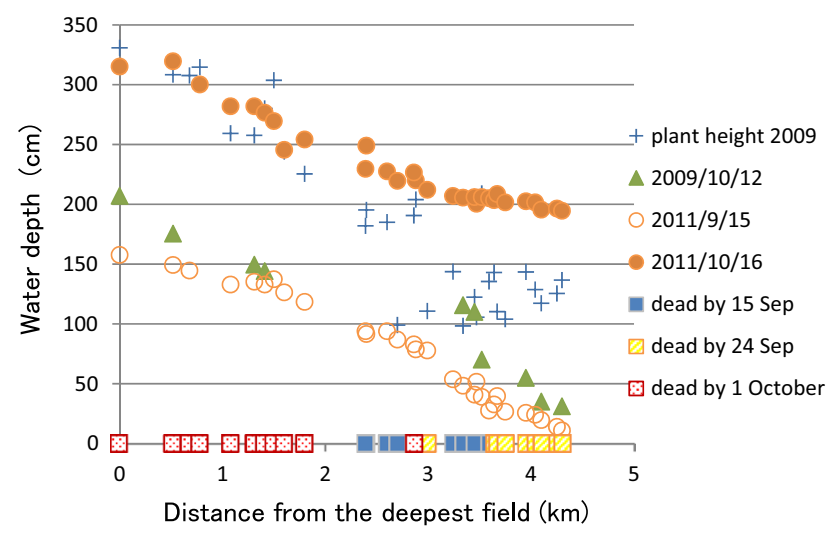

Fig. 5 Spatial distribution of maximum recorded water depth in 2009 (12 October) and 2011 (16 October), with plant height at maturity in 2009 and with water depth on 15 September 2011. Along $x$-axis, fields were grouped by the dates of complete submergence and death (by 15 September, 24 September, and 1 October 2011)

Tonle Sap Lake. In 2009 where deep water rice was harvested with only minor flood damage, the maximum level of water depth was recorded on 12 October as $2 \mathrm{~m}$ at the rice limit field, mostly shallower than $50 \mathrm{~cm}$ at flood limit field, $50 \mathrm{~cm}$ to more than $1 \mathrm{~m}$ in the middle zone (Fig. 5). A few fields in the middle zone in 2009 resulted in complete failure due to the flood in September and October. The maximum level of water depth in October 2009 was similar to the level recorded on 15 September in 2011. Considering dry-spell in July and August which sometimes retard growth of rice plants in the deep water rice area, rice plants need elongation to compete with the rise of water depth from September. In fact, the plant height of floating rice at maturity in 2009 was comparable to the maximum water depth in 2011 in the same fields (Fig. 5), which implies that if floating rice varieties had been given the sufficient time for leaf and stem elongation to compete with the rising speed of flood water level, some might have reached above the water surface and survived.

In this ecosystem, flooding period deeper than $50 \mathrm{~cm}$ was 1.5 and 2 months in the middle zone and the floating rice zone in 2009, while the duration at the corresponding zones was more than 2 and nearly 3 months in 2011, respectively. Hence, well elongating character was needed, rather than stagnant type between the middle zone and the rice limit field. The stagnant sub-1 rice may be valuable from the middle zone to the flood limit field, in years when maximum water depth was shallower but flash flood occurs. Cultivars would be needed which possess SUB1 and at the same time show some degrees of elongation due to flooding in order better to cope with the various deep water environments, and such types of germplasms lines were reported (Sarkar and Bhattacharjee 2011). Appropriate crop management was also important to cope with the dry-spell and assist plant elongation during flooding from
September, as discussed by others (Bouman et al. 2007; Puckridge et al. 1989).

However, adaptation to flood through agricultural techniques, whether by genetic improvement or by agronomic innovation, has limitation. There will be not much effective countermeasure if extremely big flood such as the one in 2011 happened. It was estimated that $53 \%$ of the water originates from the Mekong mainstream, $34 \%$ from the lake's tributaries, and the rest from precipitation (Kummu et al. 2014). Hydrological measures will be needed, such that amount of upstream water from Mekong River to Tonle Sap Lake be regulated by hydrological measures and inter-national agreement.

\section{Conclusions}

The complete damages of deepwater rice by the 2011 Southeast Asian Flood were 11-12\% in planting area in national and provincial level but more than $30 \%$ in Sangke district in Northwest Cambodia. The flooding depth and its approaching/receding speed were characterized along the transect of the floodplain of Tonle Sap Lake. Longer than one month duration of rapid flood increment $(7 \mathrm{~cm} /$ day $)$ caused complete submergence/death of floating rice in spite of its elongation ability. The field level information should be used among multi-disciplinary research groups and policy makers for developing sustainable and resilient rice production system in the floodplain of Tonle Sap Lake.

Acknowledgments We thank Dr. Takao Masumoto, NARO, Japan, for sharing the water depth data at Tonle Sap Lake. We also thank for Sophors Heng, Former Research Assistant at the Cambodian Agricultural and Development Institute, and Sovanmony In, Chanthy Suos, and Lina Pou of the Battambang Provincial Department of Agriculture, Dr. Nguyen Yen, Hanoi University of Agriculture, for their help in the field survey and statistical data collection. This study was supported in part by a Grant in-Aid for Scientific Research (No. 20405019) from the Ministry of Education, Culture, Sports, Science and Technology, and by the Environmental Research and Technology Development Fund (E-1101) of the Ministry of the Environment, Japan.

Open Access This article is distributed under the terms of the Creative Commons Attribution License which permits any use, distribution, and reproduction in any medium, provided the original author(s) and the source are credited.

\section{References}

Bouman BAM, Humphreys E, Tuong TP, Baker R (2007) Rice and water. Adv Agron 92:187-237

Buddhaboon C, Jintrawet A, Hoogenboom G (2011) Effects of planting date and variety on flooded rice production in the deepwater rice area of Thailand. Field Crops Res 124:270-277 
Catling D (1992) Rice in deep water. International Rice Research Institute, Manila. ISBN 0-333-54978-3

Catling HD, Hobbs PR, Islam Z, Alam B (1983) Agronomic practices and yield assessments of deepwater rice in Bangladesh. Field Crops Res 6:109-132

Hossain M, Bose ML, Chowdhury A (2004) Changes in agriculture and the economy in the flood-prone environment in Bangladesh, 1988-2000: insights from a repeat survey of 16 villages. In: Bhiuyan SI, Abedin MZ, Singh VP, Hardy B (eds) Rice research and development in the flood-prone ecosystem. Proceedings of the international workshop on flood-prone rice systems, Gazipur, Bangladesh, 9-11 January 2003. IRRI, Manila, pp 13-31

Ismail AM, Singh US, Singh S, Dar MH, Mackill DJ (2013) The contribution of submergence-tolerant (Sub1) rice varieties to food security in flood-prone rainfed lowland areas in Asia. Field Crops Res 152:83-94

Kummu M, Sarkkula J, Koponen J, Nikula J (2006) Ecosystem management of the Tonle Sap Lake: an integrated modelling approach. Int J Water Resour Dev 22:497-519. doi:10.1080/ 07900620500482915

Kummu M, Tes S, Yin S, Adamson P, Józsa J, Koponen J, Richey J, Sarkkula J (2014) Water balance analysis for the Tonle Sap Lake-floodplain system. Hydrol Process 28:1722-1733. doi:10. 1002/hyp.9718

Maclean JL, Dawe DC, Hardy B, Hettel GP (eds, 2002) Rice almanac. International Rice Research Institute, Los Banos; West Africa Rice Development Association, Bouake; International Center for Tropical Agriculture, Cali; Food and Agriculture Organization, Rome

Masumoto T, Tsujimoto K, Somura H (2007) Hydro-meteorological observation and analysis of observed data at Tonle Sap Lake and its environs, urban and paddy areas. Tech Rep Natl Inst Rural Eng 206:219-236
Mekong River Commission (MRC) (2010) Assessment of basin-wide development scenarios: technical note 10. The Mekong River Commission, Vientiane

Nagai K, Hattori Y, Ashikari M (2010) Stunt or elongate? Two opposite strategies by which rice adapts to floods. J Plant Res 123:303-309

Nesbitt HJ (ed) (1997) Rice production in Cambodia. International Rice Research Institute, Manila

Nguyen YTB, Kamoshita A, Araki Y, Ouk M (2013) Water availability, management practices and grain yield for deepwater rice in Northwest Cambodia. Field Crops Res 152:44-56. doi:10. 1016/j.fcr.2012.10.017

Puckridge DW, Catling HD, Vongsaroj P, Boonyawivatana S, Niyomwit L, Thongbai P (1989) Factors affecting deepwater rice in the central plain of Thailand. Field Crops Res 19:263-283

Puckridge DW, Kupkanchanul T, Palaklang W, Kupkanchanakul K (2000) Production of rice and associated crops in deeply flooded areas of the Chao Phraya delta. In: Proceedings of the international conference: the Chao Phraya Delta: historical development, dynamics and challenges of Thailand's rice bowl, 12-15 December 2000, Kasetsart University, Bangkok, Thailand. http://std.cpc.ku.ac.th/delta/conf/ Acrobat/Papers_Eng/Volume\%201/Puckridge.pdf. Accessed 20 April 2013

Sarkar RK, Bhattacharjee B (2011) Rice genotypes with SUB1 QTL differ in submergence tolerance, elongation ability during submergence and re-generation growth at re-emergence. Rice 5:7

Septiningsih EM, Pamplona AM, Sanchez DL, Neeraja CN, Vergara GV, Heuer S, Ismail AM, Mackill DJ (2009) Development of submergence-tolerant rice cultivars: the Sub1 locus and beyond. Ann Bot 103:151-160

Sommut W, Bose ML, Singh VP, Hossain M (2004) Agricultural and livelihoods in the flood-prone ecosystem in Thailand. Kasetsart $\mathrm{J}$ 25:69-89 